\title{
Expression and message style in Indonesian television advertising during the month of Ramadhan in the time of the COVID-19 pandemic period
}

\author{
M. Tohir, T. Hendiawan \& R. Belasunda \\ Telkom University, Bandung, Indonesia
}

\begin{abstract}
Advertising on television in the 2020 Ramadan in Indonesia developed in various styles and became a specific phenomenon. Several issues arise including in the way ideas and messages were conveyed in the work of television advertisements, especially in the month of Ramadan during the COVID-19 pandemic. Further efforts are needed to be able to understand, interpret, and appreciate the text of television advertisements. The purpose of this study was to understand the way form and style of television advertising is revealed and where ideas and messages from creators were conveyed. The study was conducted using the Barthes semiotic research method and interpretative descriptive techniques based on the stages of understanding, denotation, connotation, myth, and ideology. The main objective of this research was to support the increasingly active and productive role of television viewers to understand, interpret, and appreciate television commercials through academic studies.
\end{abstract}

Keywords: TV ads, ideas, messages, Ramadan, pandemic covid-19

\section{INTRODUCTION}

Advertisement is one of the cultural products that reflects the lives of its people into an inevitable part of human life. Advertising as a messenger informs us about something and asks us to buy it, the information it conveys (often) is incorrect, or even if it is true the content is a persuasion to buy products that we do not need.

Television as a medium for delivering messages has its own character. Many things can be exploited using this form of media, ranging from conversation, movement, and sounds. Television with a variety of advantages eventually became a favorite medium to deliver advertisements.

This paper tried to explore what is presented in advertising through a case study on television advertisements that aired during Ramadan 2020 which coincidentally happened during the COVID19 pandemic. It was designed to understand the kind of messages that would be conveyed besides the normative product messages that would be linked to the cultural background of making television commercials. This is because the presence of advertisements is strongly influenced by the social and cultural life of its people.

\section{METHOD}

Advertising is a form of paid communication that uses mass media and interactive media to reach a broad audience to connect clear sponsors with buyers (target audience) and provide information about products, whether in the form of goods, services, or ideas (Moriarty et al. 2018).

Television is one of the advertising media that is still the backbone of advertisers because almost every household in Indonesia has a television. Advertising on television media has various advantages compared to other media. Lee and Johnson (2011) said that television media has 
several advantages: television allows for product or service demonstration, it is easy to adapt, is cost-efficient, and attracts the attention of viewers.

Advertising on television media is a film work which is a series of images projected on the screen with the appropriate speed aimed at creating the illusion of continuous motion (Danesi 2010). Film as a medium aims to convey cultural events/practices and social phenomena to a wide audience with mass communication through the mass media system. In the context of film as a medium of communication, and creators act as senders of messages or ideas, ad viewers as readers of ideas, and the ads themselves as the media through which the ideas are conveyed.

Film as an object/artifact consists of the physical structure and its constituent elements. The structure of the film consists of shots, scenes, and sequences. The constituent elements consist of narrative elements (story and plot, characterization, main elements, space, time, and story information) and cinematic elements (mise-en-scene, cinematography, editing, and sound) (Pratista 2008).

Semiotics generally talks about signs. Signs are described as anything that produces meaning. They can represent/reflect things that are in/about the world, more specifically in the social world. Signs not only convey meaning but also produce meaning; even one sign can have multiple meanings.

Ferdinand de Saussure, a linguist (Fiske 2007) said that a sign is a physical object with meaning, or, to use the term, a sign consisting of a marker. Markers are images of signs as we perceive them, such as writings on paper or sounds in the air. A sign is a mental concept that is referred to by it. This mental concept is broadly the same in all members of the same culture who use the same language. In line with that, Williamson (2007) said that a sign is something (a thought) that can be an object, word, or picture that has a certain meaning for a person or group of people. A sign is not just a thing and not just a meaning but both at once.

Many definitions of the meaning offered by linguists and philosophers, but for the study of television advertising the author refers to the method that was stated by Barthes (Fiske 2007), which divides meaning into two domains: denotation, which is something (words) which does not contain additional meanings or feelings, and connotation, which is something (words) that contains additional meanings, certain feelings, or certain taste values besides general basic meanings. This will illustrate how an advertisement is denoted and then get its meaning after interacting with the audience. And then it continues to the concept of myth as a way of thinking, conceptualizing, and understanding about culture, and the concept of ideology as a false beliefs.

\section{RESULT AND DISCUSSION}

Based on observations of television advertisements during Ramadan 2020, there were 20 television commercials that had a high broadcast frequency and can be grouped into 2 categories: products and services. Product categories consisted of brands: Khong Guan, Teh Botol Sosro, Mc. Donald, Enervon C, Nutricake, Top Coffee, Ciptadent Herbal, Milo, Pocky, Esemag, Dancow, Indofood Bumbu Racik, HerbaKof, Kraft Cheddar, Brightgas Pertamina, Indomie, and Bejo Jahe Merah. The service category consisted of brands: Roma Festive, Shopee, and Blibli.

In general, the messages conveyed in these advertisements were: (a) benefits and product positioning; and/or (b) how the product relates to the current conditions of Ramadan and the COVID-19 pandemic. From the available data, the Teh Botol Sosro product (Ramadan 2020 edition, 60 sec, Flock Creative Network) was interesting to be used as a sample for further research because it had a way of conveying messages (styling) that was relatively different from other products advertised on television during Ramadan 2020.

What follows is the analysis of Teh Botol Sosro ad text on narrative and cinematic elements as a sign and sign system.

The results of the analysis are that many of the cinematics' style uses subjective camera angles in an effort to bring the audience closer to the subject or object in the ad. Narrative construction emphasizes semiotic, semantic, and cinematic elements. These elements are used to build the empathy and sympathy of the audience. 
Table 1. Text analysis: visual and semantic films

\begin{tabular}{|c|c|c|c|}
\hline & Visual Narration & Verbal Narration & Cinematic Elements \\
\hline 1 & & $\begin{array}{l}\text { Ramadhan kali ini terasa } \\
\text { sedikit berbeda }\end{array}$ & $\begin{array}{l}\text { The camera angle is subjective, its angle is } \\
\text { low. The object of the bridge is silhouetted } \\
\text { against the background of the mosque from the } \\
\text { green. } \\
\text { Ramadan is a special month for Muslims to get } \\
\text { closer to the almighty. } \\
\text { The visuals displayed are a limitation, distance, } \\
\text { and silence. }\end{array}$ \\
\hline 2 & & & $\begin{array}{l}\text { Subjective camera angles; a straight angle was } \\
\text { used on the camera and it uses symmetric } \\
\text { compositions. The object of focus is someone } \\
\text { praying inside the mosque. } \\
\text { Closed, trapped, and alienation of someone } \\
\text { who worships in the mosque. }\end{array}$ \\
\hline 3 & & $\begin{array}{l}\text { Hari demi hari ada yang } \\
\text { setia berdiri demi semua } \\
\text { kebutuhan terpenuhi }\end{array}$ & $\begin{array}{l}\text { Subjective camera angles; a straight angle is } \\
\text { used on the camera and it uses a symmetrical } \\
\text { composition with neutral screen direction. The } \\
\text { object of focus is a security person standing } \\
\text { under the bridge. } \\
\text { Interpreted as protection and hope. }\end{array}$ \\
\hline 4 & & & $\begin{array}{l}\text { Subjective camera angles; a straight angle is } \\
\text { used on the camera and it uses a symmetrical } \\
\text { composition with neutral screen direction. The } \\
\text { object of focus is a policeman standing on the } \\
\text { side of the road. } \\
\text { Interpreted as charm, protection, and hope. }\end{array}$ \\
\hline 5 & & $\begin{array}{l}\text { Ada yang turun kejalan, } \\
\text { sukarela menambah } \\
\text { beban demi kurangi } \\
\text { beban sekitar }\end{array}$ & $\begin{array}{l}\text { Subjective camera angles; a straight angle is } \\
\text { used on the camera and it uses a symmetrical } \\
\text { composition with neutral screen direction. The } \\
\text { object of focus is a nurse walking on the side } \\
\text { of the road. } \\
\text { Interpreted as caring and togetherness. }\end{array}$ \\
\hline
\end{tabular}

Subjective camera angles; a straight angle is

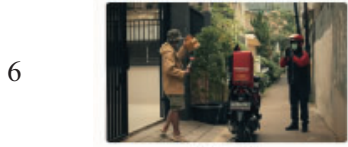
used on the camera and it uses a symmetrical composition with contrasting screen direction. The object of focus is someone ordering MC D.

Interpreted as caring and togetherness

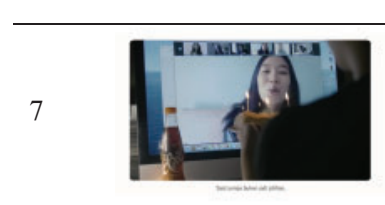

Saat jumpa bukan
menjadi pilihan

Subjective camera angles; a high camera angle is used, and using over-shoulder withn neutral screen direction. The object of focus is a person having an online interaction. Interpreted as search and happiness

$\begin{array}{ll}\text { Ada yang ikhlas } & \text { Subjective camera angle; a high camera angle } \\ \text { menyambung ikatan } & \text { is used, the object of focus is two children } \\ \text { interacting, but separated by a windowpane } \\ \text { between them. } \\ \text { Interpreted as breaking the line, subordinate }\end{array}$




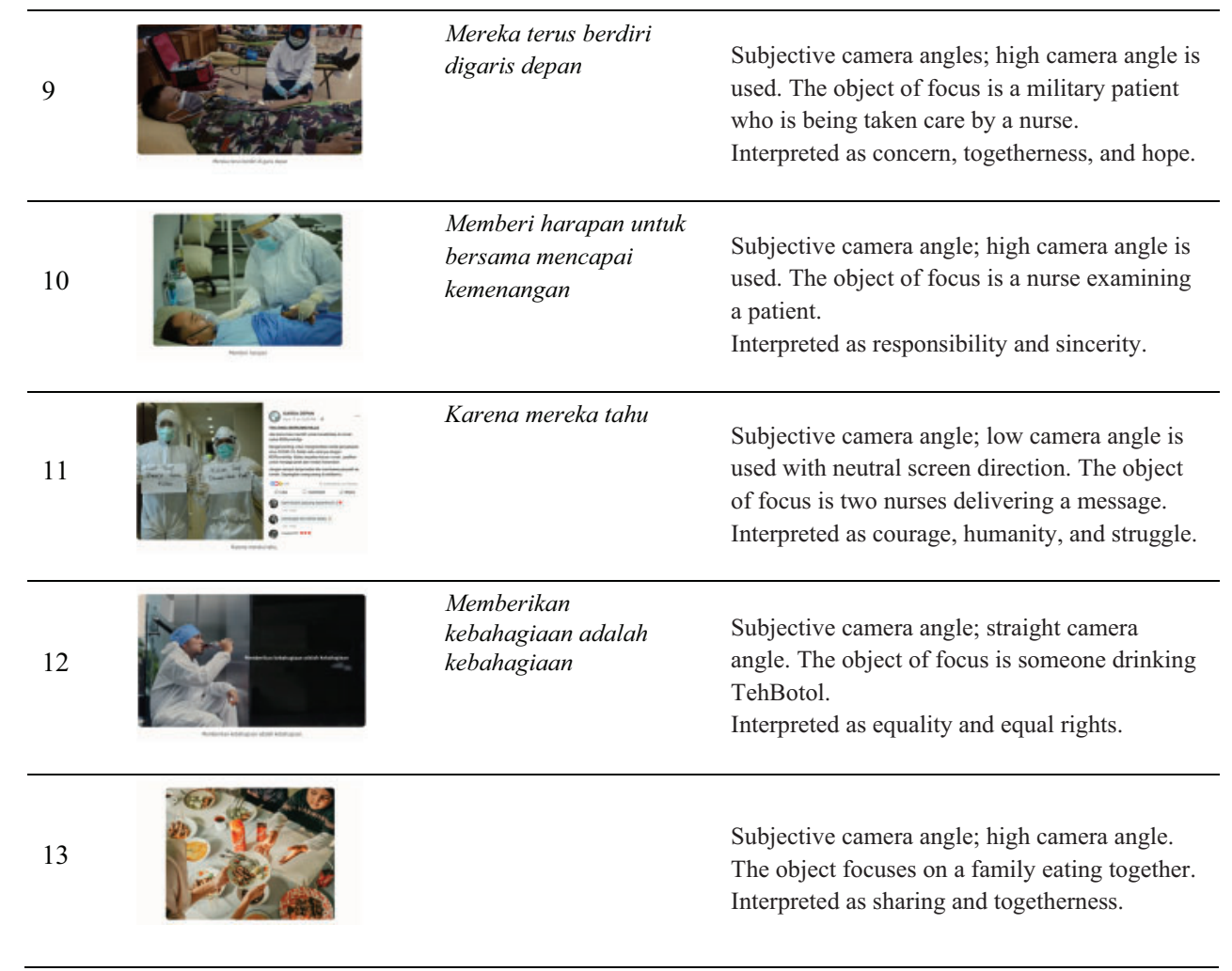

Visual analysis of the first myth: Eid is a sacred thing and important in achieving happiness for every Muslim. The word "happiness" is a modern myth that must be achieved after a full month of fasting. However, during this COVID-19 pandemic, the meaning of happiness has changed. Second, Teh Botol Sosro product tried to instill an ideology of false consciousness through poetic narratives to build the connotation of "happiness" through its product as a metaphorical truth.

\section{CONCLUSION}

It could be concluded that there is a mythical battle about "happiness" between cultural systems (thinking) with materials or products (having) through social systems (doing) that cause ideological problems. Ideological problems and representations in the Teh Botol Sosro advertisement (Ramadan 2020 edition) form ideological awareness and representation.

The ideological status is related to awareness, beliefs, and concepts of the value system. Ideology has a fundamental connotation, so that the advertisement is a false awareness and there is an effort of idealization in cultural systems toward individuals and society. This is "emotional hypnotism", meaning that individuals and the community will always need or require these products to achieve happiness.

The representation contains the purpose of describing the reality as it is in the form of facts and current conditions. In the meanwhile, the imitation of reality is related to Teh Botol Sosro products about false consciousness and questions the reality of happiness itself.

\section{REFERENCES}

Danesi, M. 2010. Pesan, Tanda, dan Makna: Buku Teks Dasar Mengenai Semiotika dan Teori Komunikasi. A. Adlin (Ed). Yogyakarta: Jalasutra. 
Fiske, J. 2007. Cultural and Communication Studies. Yogyakarta: Jalasutra.

Kumpulan Iklan Edisi Bulan Ramadhan \#22 https://www.youtube.com/channel/UCBTqzsrxGdTRAmWg0F2 bcoQ (7-8-2020)

Lee, M. and Johnson, C. 2011. Prinsip-prinsip Pokok Periklanan Dalam Perspektif Global Cetakan ke-3. Penerjemah: Haris Munandar, Dudi Priatna. Jakarta: Kencana.

Moriarty, S., Mitchell, N., and Wells, W. 2018. Advertising. Jakarta: Prenadamedia Group.

Pratista, H. 2008. Memahami Film. E. Damayati (Ed). Yogyakarta: Homerian Pustaka.

Williamson, J. 2007. Decoding Advertisements: Membedah Ideologi dan Makna dalam Periklanan. Penerjemah: Saleh Rahmana. Editor: Alfatri Adlin. Yogyakarta: Jalasutra. https://swa.co.id/swa/businessupdate/tehbotol-sosro-dan-flock-creative-network-apresiasi-garda-terdepan-di-tengah-covid-19 (7-10-2020) 